\title{
Factors Affecting Income Of Female Workers Producing Ketupat Casing and Their Contribution to Household Income
}

\author{
By \\ Siska Marwati, Dijan Rahajuni ${ }^{*}$, Supadi \\ Faculty of Economics and Business, Jenderal Soedirman University \\ ${ }^{*}$ Corresponding Author : dijan_rahajuni@yahoo.com
}

Submission: November 18, 2019; Accepted: February 26, 2020

\begin{abstract}
This study aims to examine the effect of education level, working time, age, work experience and number of family members on income of female workers in Datar Village and measure the extent of income contribution of female workers producing ketupat casing to household income. The respondents were selected using the census method and data were analyzed using multiple linear. This study found that education level, working time, work experience and number of family members had a significant effect on income of female workers. Age had no effect on income of female workers. The variable with the strongest relationship to income of female workers was working time. The implications of this study are that in order to increase their income, the female workers should utilize the residue of ketupat casing production in the form of coconut sticks to make other handicrafts, such as woven plates and broom sticks. The crafts can be sold in order to increase income of female workers producing ketupat.
\end{abstract}

Keywords :Income, Female Worker, Rural Development

\section{ABSTRAK}

Penelitian ini bertujuan untuk menguji pengaruh tingkat pendidikan, curahan waktu kerja, usia, pengalaman kerja dan jumlah anggota keluarga terhadap pendapatan buruh wanita di Desa Datar dan mengukur seberapa besar kontribusi pendapatan buruh wanita pembuat selongsong ketupat terhadap pendapatan rumah tangga. Responden dipilih menggunakan metode sensus dan data dianalisis dengan regresi berganda. Hasil penelitian menunjukkan bahwa tingkat pendidikan, curahan waktu kerja, pengalaman kerja dan jumlah anggota keluarga berpengaruh signifikan terhadap pendapatan buruh wanita. Usia tidak berpengaruh terhadap pendapatan buruh wanita. Variabel yang memiliki hubungan paling kuat terhadap pendapatan buruh wanita yaitu curahan waktu kerja. Pendapatan buruh wanita memiliki kontribusi besar terhadap pendapatan rumah tangga. Hasil penelitian mengimpilkasikan bahwa untuk meningkatkan pendapatanya, para buruh wanita dapat memanfaatkan sisa pembuatan selongsong ketupat berupa lidi untuk menjadi kerajinan lain seperti piring anyaman dan sapu lidi. Kerajinan dapat dijual agar dapat menambah pendapatan para buruh wanita pembuat selongsong ketupat.

Kata Kunci : Pendapatan, Buruh Wanita,Pembangunan Perdesaan 
Factors Affecting Income .... (Marwati, et al.)

\section{INTRODUCTION}

As a developing country, Indonesia is characterized by low per capita income (Ministry of Education and Culture, 2018: 3). Per capita income is an important element in meeting the needs of life. Low per capita income suggests low consumption to meet the needs of life. This is caused by financial activities that are based on the industrial and service sectors. Therefore, to improve the economy at this time has emerged various kinds of creative industries initiated by women. This is caused by insufficient husband's income to meet the economic needs of the family, thus encouraging women to participate in meeting family needs. It can be seen in Table 1 that the number of female labor force has increasedin 2014-2018.

Table 1. Number of Female Labor Force Aged 15 Years and Over in Indonesia in 2014-2018 (in thousands)

\begin{tabular}{lccccc}
\hline Type of Activity & 2014 & 2015 & 2016 & 2017 & 2018 \\
\hline Labor force & 48,458 & 50,390 & 49,534 & 52,539 & 53,741 \\
Work & 45,630 & 47,422 & 46,931 & 49,772 & 51,112 \\
Open unemployment & 2,828 & 2,968 & 2,603 & 2,767 & 2,629 \\
Not in labor force & 42,334 & 42,096 & 44,441 & 42,919 & 43,190 \\
School & 8,076 & 8,437 & 8,177 & 7,665 & 7,883 \\
Taking care of household & 31,482 & 30,889 & 33,472 & 32,580 & 32,632 \\
Others & 2,775 & 2,770 & 2,792 & 2,673 & 2,675 \\
\hline Labor force participation rate & 50.26 & 54.48 & 52.71 & 55.04 & 55.44 \\
(percent) & & & & & \\
\hline
\end{tabular}

Source: Indonesian Central Statistics Agency, 2018

Number of female labor force has increased from 48,458 people in 2014 to 53,741 people in 2018. The female labor force participation rate also increases to 55.44 percent in 2018. The increasing number of female labor force in Indonesia is caused by several factors, including: a change in views and attitudes in society that women need to participate in the development, women's role to increase family income, and wider employment opportunities for women (Setyowati, 2009:216). With the increase in the number of female labor force, the government should be able to provide employment to prevent unemployment.

Employment with the highest number of female labor force is in informal sectors, such as trade, service, manufacturing, and other sectors. The percentage of female workers is greater in the informal sectors than in the formal sectors (Armansyah, 2017: 32). Informal sector has the ability to provide employment. This is because labor force absorbed in the formal sector is limited and the informal sector can create new jobs without government assistance (National Development Planning Agency, 2009: 32). The percentage of formal and informal workers in Banyumas Regency in 2013-2015 can be seen at Table 2.

Table 2. Percentage of Formal and Informal Workers in Banyumas Regency (percent) 2013-2015

\begin{tabular}{lccc}
\hline \multicolumn{1}{c}{ Worker } & 2013 & 2014 & 2015 \\
\hline Formal Worker & 25.47 & 28.29 & 30.81 \\
Informal Worker & 74.53 & 71.71 & 69.19 \\
\hline
\end{tabular}

Source: Banyumas Central Statistics Agency, 2017

Table 2 shows that the percentage of workers in formal and informal sectors tend to increase every year. However, the number of workers in informal sector decreases to 69.19 percent in 2015. But compared to the formal sector, the informal sector is able to absorb more labor force. This means that the informal sector has an important role in overcoming unemployment in Banyumas Regency. This is because the jobs in the informal sector have a flexible time, meaning that in addition to increasing family income, they can fulfill their main function to carry out household tasks. Moreover, 
there are no special requirements for entering the informal sector, such as education level, age, and work experience (Noeraini, 2015: 5).

One of the informal sectors in Banyumas Regency is Ketupat craft in Datar Village, Sumbang Sub-District. Although the ketupat craft has not been registered as a legal entity, a large number of women are interested in becoming female workers producing ketupat casing. According to Manpower, Cooperative and Small \& Medium Enterprises Department (2018), the number of ketupat crafters in Datar Village is 11 people with 28 female workers producing ketupat casing.

Table 3. Number Of Female Workers In The Production Of Ketupat Crafters in Datar Village Sumbang Sub-district in 2014-2018

\begin{tabular}{cc}
\hline Years & Female Workers In The Production Of Ketupat Crafters \\
\hline 2014 & 28 \\
2015 & 36 \\
2016 & 39 \\
2017 & 43 \\
2018 & 51 \\
\hline
\end{tabular}

Source: Processed data, 2018

Table 3 shows the increasing number of female workers producing ketupat casing from 2014 to 2018. The increasing number of female workers is caused by several things, namely; female workers working as ketupat crafter are able to increase family income, the production of ketupat casing is carried out at the home of female workers without leaving their home. The crafters deliver coconut leaves to female workers in the morning and take finished ketupat casing in the afternoon. The price of a ketupat casing is Rp.30/unit. In a day, the female workers can produce 300-1.000 ketupat casings. The production depends on the speed and amount of time spent in producing ketupat casing. The income received is in accordance with the volume of ketupat casing production.

The female workers consider that the income received from ketupat casing production is sufficient, so that a large number of women are interested in becoming ketupat craftswomen because they consider that the income earned can help meet family needs. This has caused the number of female workers to increase every year. This study aimed to examine the effect of education level, working time, age, work experience and number of family members on the income of female workers in Datar Village and measure the income contribution of female workers on household income.

\section{METHOD}

This is quantitative research and this study used census method. Census is data collection by investigating all population (Supranto, 2009: 18). There were two types of data sources used in this study, namely primary data and secondary data. Primary data was obtained by conducting direct interview with female workers producing ketupat casing. While secondary data were btained Central Statistics Agency (BPS), Manpower and SMEs Department. Population in this study consist of 50 female workers producing ketupat casing in Datar Village Sumbang Sub-District. Data collection in this study used the entire population because the size of population was small.

Data analysis technique in this study was multiple linear. Multiple linear was used to determine the effect of education level $\left(X_{1}\right)$, working time $\left(X_{2}\right)$, age $\left(X_{3}\right)$, work experience $\left(X_{4}\right)$, number of family members $\left(X_{5}\right)$ on income of female workers $(Y)$. These variables were transformed into natural logarithms. Natural logarithms were used in this study because the data varied with different units. The multiple regression model with natural logarithms was as follows(Widarjono,2009: 54) :

$$
\mathrm{Y}=\boldsymbol{\alpha}+\beta 1 \mathrm{X}_{1}+\beta 2 \mathrm{X}_{2}+\beta 3 \mathrm{X}_{3}+\beta 4 \mathrm{X}_{4}+\beta 5 \mathrm{X}_{5}+\mu
$$

The variables were transformed into natural logarithms:

$$
\ln \mathrm{Y}=\alpha+\beta 1 \operatorname{In} \mathrm{X}_{1}+\beta 2 \operatorname{In} \mathrm{X}_{2}+\beta 3 \operatorname{In} \mathrm{X}_{3}+\beta 4 \operatorname{In} \mathrm{X}_{4}+\beta 5 \operatorname{In} \mathrm{X}_{5}+\mu
$$


In this study, the model has the form:

$$
\operatorname{In} \mathrm{Y}=\alpha+\beta 1 \operatorname{In} \mathrm{EL}+\beta 2 \operatorname{In} \mathrm{WT}+\beta 3 \operatorname{In} \mathrm{A}+\beta 4 \operatorname{In} \mathrm{WE}+\beta 5 \operatorname{In} \mathrm{NFM}+\mu
$$

Description :

$\begin{array}{ll}\text { In } & =\text { Log-linier } \\ Y & =\text { Income of female workers } \\ \alpha & =\text { Intercept } \\ E L & =\text { Education level } \\ W T & =\text { working time (hour) } \\ A & =\text { Age (year) } \\ W E & =\text { work experience (year) } \\ N F M & =\text { number of family members (people) } \\ \mu & =\text { error term }\end{array}$

To determine whether or not there is a relationship between independent variable and dependent variable simultaneously or partially, this study used hypothesis testing, namely F-test, $\mathrm{t}$ test, and coefficient of determination. Correlation test was used to determine which variable that has a relationship to income of female workers, while contribution analysis was used to determine the extent of income contribution of female workers to family income.

\section{RESULT AND DISCUSSION}

To determine the effect of education level, working time, age, work experience and number of family members variables on income of female workers producing ketupat casing in Datar Village, it was used multiple regression analysis with natural logarithms.

Table 4. Estimation Result of Multiple Regression Analysis

\begin{tabular}{lcc}
\hline \multicolumn{1}{c}{ Variable } & Coefficient & P Value \\
\hline C & 9.663 & 0.000 \\
Education Level $\left(X_{1}\right)$ & 0.372 & 0.032 \\
Working Time $\left(X_{2}\right)$ & 1.190 & 0.000 \\
Age $\left(X_{3}\right)$ & -0.099 & 0.182 \\
Work Experience $\left(X_{4}\right)$ & 0.222 & 0.000 \\
Number of Family Members $\left(X_{5}\right)$ & 0.219 & 0.005 \\
\hline
\end{tabular}

Source: Primary data processed

Based on the result of multiple linear regression, the following

$$
\ln Y=9,663+0,372 \ln X_{1}+1,190 \ln X_{2}-0,099 \ln X_{3}+0,222 \ln X_{4}+0,219 \ln X_{5}
$$

The classical assumption test consists of normality test, multicollinearity test, heteroscedasticity test, and autocorrelation test. In this study, normality was tested using One sample KolmogorofSmirnov test. If ( 2 -tailed) $p$ value $\geq 0.05$, then the data is normally distributed and if ( 2 -tailed) $p$ value $<0.05$, then the data is not normally distributed. Based on the test, it was found that $p$ value (Asymp. Sign 2 tailed) of $0.914>0.05$, meaning that the standardized residual value was normally distributed. Multicollinearity was tested using TOL (Tolerance) and VIF (Variance Inflation Factors) methods. Based on the test, was obtained. 
Table 5. Multicollinearity Test

\begin{tabular}{lcc}
\hline \multicolumn{1}{c}{ Variable } & Tolerance & VIF \\
\hline Education Level & 0.908 & 1,101 \\
Working Time & 0.287 & 3.479 \\
Age & 0.987 & 1.014 \\
Work Experience & 0.354 & 2.821 \\
Number of Family Members & 0.671 & 1.489 \\
\hline
\end{tabular}

Source: Primary data processed

Based on Table 5, it can be seen that the VIF value in each variable is less than 10 and the tolerance value is greater than 0.10 , then it can be said that the regression model is free from multicollinearity problems.

Heteroscedasticity test used Glejser method. Based on the test, the following result was obtained.

Table 6. Results of Heteroscedasticity Test

\begin{tabular}{cc}
\hline Obs*R-squared & Probability \\
\hline 4.926 & 0.425 \\
\hline \multicolumn{2}{c}{ Source: Primary data processed }
\end{tabular}

Based on Table 6, it can be seen that the probability value of each variable is greater than 0.05 , meaning that the regression model is free from heteroscedasticity problems.

The autocorrelation in this study was tested using Durbin Watson Test (DW Test). Based on the test the following result was obtained.

Table 7. Results of Autocorrelation Test

\begin{tabular}{ccccc}
\hline$R$ & $\begin{array}{c}R \\
\text { Square }\end{array}$ & $\begin{array}{c}\text { Adjusted } R \\
\text { Square }\end{array}$ & $\begin{array}{c}\text { Std. Error of the } \\
\text { Estimate }\end{array}$ & $\begin{array}{c}\text { Durbin- } \\
\text { Watson }\end{array}$ \\
\hline $0.958^{a}$ & 0.918 & 0.909 & 0.138 & 2.014 \\
\hline
\end{tabular}

Source: Primary Data processed

Based on autocorrelation test, it is obtained $\mathrm{dL}$ value of 1.335 and $\mathrm{dU}$ value of 1.771 . The result indicates that DW position is between $\mathrm{dU}$ and 4-du. Thus, it can be concluded that the model is free from autocorrelation problems.

$F$ test often referred to as simultaneous test was used to determine whether the independent variables in the model simultaneously have a significant effect on the dependent variable (Suliyanto, 2011: 44).Based on the test the following result was obtained results.

Table 8. F Test

\begin{tabular}{cr}
\hline \multicolumn{2}{c}{ Weighted Statistics } \\
\hline F-statistic & 101.316 \\
F-table & 2.574 \\
Prob(F-statistic) & 0.000 \\
\hline
\end{tabular}

Source: Primary data processed

Based on Table 8, it is obtained F-statistic of 101.316 with $p$ value of 0.0000 . Thus, it can be concluded that all the independent variables (education level, working time, age, work experience and number of family members) simultaneously have a significant effect on the dependent variable (income of female workers producing ketupat casing).

T-test was used to test whether each independent variable has a significant effect on the dependent variable. Based on the test, it the following result was obtained. 
Table 9. Result of T-Test

\begin{tabular}{lcc}
\hline \multicolumn{1}{c}{ Variable } & t-statistic & P Value \\
\hline Education Level & 2.208 & 0.032 \\
Working Time & 6.075 & 0.000 \\
Age & -1.357 & 0.182 \\
Work Experience & 6.198 & 0.000 \\
Number of Family Members & 2.992 & 0.005 \\
\hline
\end{tabular}

Source: Primary data processed

It can be seen that the t-statistic of education level (EL) is 2.208 with $p$ value of 0.032 . The coefficient of education level is 0.372 . This means that any increase in the education level by 1 percent will increase the income of female worker producing ketupat casing by 0.372 percent. This indicates that education level variable has a significant and positive effect on income of female workers producing ketupat casing. Education is one's basic capitals needed to work, including skills, knowledge and independence. Therefore, the higher the education level, the higher their ability to work (Sumarsono, 2003: 15). Based on the basic assumption of Human Capital, the higher one's education level, the higher income earned (Simanjuntak, 2001: 21). The result of this study is in accordance with the study conducted by Dewi (2012: 124) and kabir,et al (2019) that education level variable has a positive effect on the income of female workers. The positive effect of education level on the income of female workers producing ketupat casing indicates that the increasing education level will improve one's skills, so that it will increase one's ability to work.

The t-statistic of working time (WT) is 6.075 with $p$ value of 0.000 . The coefficient of working time is 1.190. This means that any increase in working time by 1 percent will increase the income of female worker producing ketupat casing by 1.190 percent. This indicates that working time variable has a significant and positive effect on income of female workers producing ketupat casing. The more working time, the more income earned(Mubyarto, 1985: 13). The more time spent by female workers to make ketupat casing, the more income earned. The result of this study is in accordance with the study conducted by Yuli (2011: 58) that working time variable has an effect on income of female workers.

The t-statistic of age (A) is -1.357 with $p$ value of 0.182 . The coefficient of age is -0.099 . This means that any increase in age by 1 percent will decrease income of female workers producing ketupat casing by -0.099 percent. This indicates that age variable has insignificant and negative effect on income of female workers producing ketupat casing. The result of this study is in accordance with the study conducted by Dewi (2012: 123) that age has a negative effect on income of female workers. However, the result of this study contradicts Haque, et.al's study (2017: 128) and Garo's study (2018) that age has a positive effect on income of female workers.

The t-statistic of work experience (WE) is 6.198 with $p$ value of 0.000 . The coefficient of work experience is 0.222 . This means that any increase in work experience by 1 percent will increase income of female workers producing ketupat casing by 0.222 percent. This indicates that work experience variable has a significant and positive effect on income of female workers producing ketupat casing. The longer a person is engaged in a particular job, then they will master the job (Simanjuntak, 2001: 81). Therefore, the longer work experience, the more income earned. The result of this study has supported Yuli (2011: 62) that work experience has a significant and positive effect on income of female workers. However, the result of this study contradicts Dijan et.al's study (2009: 108) that work experience has insignificant and negative effect on income of female workers.

The $t$-statistic of Number of Family Members (NFM) is 2.992 with $p$ value of 0.005 . The coefficient of number of family members is 0.219 . This means that any increase in number of family members by 1 percent will increase income of female workers producing ketupat casing by 0.219 percent. The result of this study is in accordance with the study conducted by Godara (2017:5) and Umbreen (2017) that number of family members variable has a positive effect on income of female workers. 
Based on coefficient of determination $\left(R^{2}\right)$, goodness of fit $\left(R^{2}\right)$ value is 0.918 . This means that 91.8 percent of income of female workers producing ketupat casing is explained by education level, working time, age, work experience, and number of family members variables, while the remaining 8.2 percent is explained by other variables not included in the model

The correlation test used the Pearson product-moment correlation coefficient. If the correlation coefficient is closer to one, the correlation coefficient becomes stronger. If the correlation coefficient is closer to 0 , then the correlation coefficient becomes weaker.

Table 10. Result of Correlation Test

\begin{tabular}{lc}
\hline \multicolumn{1}{c}{ Variable } & Income of Female Worker \\
\hline Education Level & 0.076 \\
Working Time & 0.914 \\
Age & -0.063 \\
Work Experience & 0.874 \\
Number of Family Members & 0.507 \\
\hline
\end{tabular}

Source: Data processed

Based on the result of correlation test, working time variable has the highest correlation value of 0.914 compared to the other four variables. This means that working time variable has the strongest relationship to the income of female workers producing ketupat casing. This is in accordance with Yuli's study (2011: 58) that working time has the strongest relationship on income of female workers.

The income contribution in this study is the percentage of contribution or contribution of female workers producing ketupat casing to family income. To determine the extent of contribution of female workers producing ketupat casing to family income, the following results are obtained.

$$
\begin{aligned}
\text { Contribution of female workers } & =\frac{\text { Average income of female workers producing ketupat casing }}{\text { Average total family income }} \times 100 \% \\
& =\frac{557,647.06}{1,660,588.24} \times 100 \% \\
& =33.58 \%
\end{aligned}
$$

The income contribution of female workers producing ketupat casing is 33.58 percent of the average family income. The result of this study is in accordance with the study conducted by Haryanto (2008: 224) that the income of female workers contribution to family income and the study conducted by Roy,et.al (2017) found that women's income has contributed to household income by 43.52 percent.

\section{CONCLUSION}

Based on the analysis and results of this study, it can be concluded that education level, working time, age, work experience, and number of family members variables simultaneously had an effect on income of female workers producing ketupat casing variable, but age variable had no effect on income of female workers producing ketupat casing. Working time had the strongest relationship to income of female workers producing ketupat casing. The income of female workers producing ketupat casing had major contribution to family income.

The implications of this study are that as an effort to continue to increase their income, female workers producing should be able to utilize the residue of ketupat casing production in the form of coconut sticks to make other handicrafts such as woven plates or broom sticks. The crafts can be sold to increase the income of female workers producing ketupat casing. The income of female workers producing ketupat casing has major contribution to family income. Therefore, they are expected to produce more ketupat casings in order to increase income. 
This study only covered a village, namely Datar Village. Further studies are expected to be conducted in the areas in Banyumas Regency. There were limited data to find out the number of female workers producing ketupat casing, thus the researcher had to conduct direct survey to find out the number of female workers producing ketupat casing. Moreover, the female workers filled the questionnaire and answered the questions provided by the researcher. As a result, the information obtained was incomplete. Further studies can use more variables that the resulting model can be better in explaining the income of female workers producing ketupat casing.

\section{REFERENCE}

Armansyah. (2017). Karakteristik dan Peluang Tenaga Kerja Wanita pada Sektor Informal. Demography Journal of Sriwijaya, 1 (2), 32-36.

Awan, A., Faridi, M., \& Abbas, M. (2015). Factors Affecting Women Contribution in Household Budget in Urban Informal Sektor: An Analysis. Journal of Human-Social Science, 15 (1), 4-15.

Badan Pusat Statistik. (2018). Data Statistik Indonesia. Jumlah Angkatan Kerja, Bukan Angkatan Kerja dan TPAK Tahun 2015-2017 di Indonesia. Jakarta: Badan Pusat Statistik. Accessed from http://www.bps.go.id

Badan Pusat Statistik.(2017). Statistik Daerah Kabupaten Banyumas. Banyumas: Badan Pusat Statistik Banyumas. Accessed from http://www.bps.go.id

Bappenas. (2009). Peran Sektor Informal sebagai Katup Pengaman Masalah Ketenagakerjaan 2009. Jakarta: Bappenas. Accessed from http://www.bapppenas.go.id

Dewi, P. Martini. (2012). Partisipasi Tenaga Kerja Perempuan dalam Meningkatkan Pendapatan Keluarga. Journal of Applied Quantitative Economics, 5 (2), 119-124.

Dinas Tenaga Kerja, Koperasi dan UKM. (2018). Data Sektor Perdagangan, Hotel Restoran Kecamatan Sumbang. Regional Archive: Unpublished.

Garo, Orion. (2018). Wages and Human Capital Potention in The Albanian Labour Market: Comparing Albanian Workforce productivity and Labour Market Earning To Those in Neighbouring Countries. Journal Labour and Social, 21 (1), 95-115.

Godara, A., Varsha. (2017). Analysis of Rural Women Participation in Decision-Making in Agricultural Sektor and Factors Affecting it: A Case Study of Jind District of Haryana State. Journal Economics, 3 (5), 307-310.

Haryanto, S. (2008). Peran Aktif Wanita Dalam Peningkatan Pendapatan Rumah Tangga Miskin :Studi Kasus Pada Wanita Pemecah Batu di Pucanganak Kecamatan Tugu Trenggalek. Journal of Development Economics, 9 (2), 216-227.

Kabir, Md.Shajahan., Mirjana, M., \& Radulovi, D.(2019). The Determinants of Income of Rural Women in Bangladesh. Journal sustainability, 11 (20), 2-13.

Kementerian Pendidikan dan Kebudayaan RI. (2018). Negara Maju dan Berkembang.(Permendiknas Nomor 8 tahun 2018). Jakarta: Penulis. Accessed fromhttp://spi.um.ac.id

Mubyarto. (1989). Pengantar Ekonomi Pertanian. Jakarta: LP3ES

Noeraini, A. Amalia. (2015). Ekonomi Informal di Indonesia, Suatu Tinjauan Pustaka. Journal of Development Economics, 5 (1), 1-18.

Rahajuni, D., Gunawati, E. Sri, \& Suryahani, I. (2009). Kontribusi Besar Pendapatan Wanita Pemulung Terhadap Pendapatan Keluarga (Studi Kasus Pada Wanita Pemulung di TPA Gunung Tugel Kabupaten Banyumas). Journal of Regional Economics, 4 (2), 105-110.

Roy, Haque, Jannat, \& Khan. (2017). Contribution of Women to Household Income and Decision Making in Some Selected Areas of Mymensingh in Bangladesh. Journal of Agriculture, 28 (2), 120-129.

Setyowati, E. (2009). Analisis Tingkat Partisipasi Wanita dalam Angkatan Kerja di Jawa Tengah Periode Tahun 1982-2000. Journal of Development Economics, 10 (2),215-233.

Simanjuntak, P. (2001). Pengantar Ekonomi Sumber Daya Manusia. Jakarta: LPFUI

Suliyanto. (2011). Ekonometrika Terapan : Teori \& Aplikasi dengan SPSS. Yogyakarta: Andi 
Sumarsono, S. (2003). Ekonomi Manajemen Sumber Daya Manusia dan Ketenagakerjaan. Yogyakarta: Graha IImu

Supranto, J. (2009). Statistik Teori dan Aplikasi. Jakarta: Erlangga

Umbreen, F. Kokab, A. (2017). Women Participation in Gujarat, Pakistan. Journal of Scientific and Emgineering Research, 8 (1), 789-799.

Yuli, S., Cantika, B. (2011). Kontribusi Pendapatan Usaha Industri Kecil Keripik Usus Terhadap Pendapatan Rumah Tangga di Desa Kanjuruhan Kecamatan Kepanjen Kabupaten Malang. Journal of Development Economics, 7 (1), 53-63. 